\title{
Proximate and minerals compositions of three species of fish, Champsocephalus gunnari, Oreochromis niloticus and hybrid catfish sold in Birnin Kebbi, Kebbi State, Nigeria
}

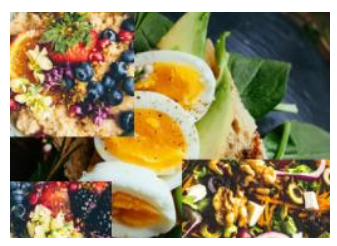

* Correspondence:

Nathaniel O. Iboyi (AISLT)

Tel: +2347038313057, Email: nathanieliboyi6@gmail.com

AROC in Food and Nutrition, 2021, 01(01), 08-14 Delta State. Nigeria

\author{
Nathaniel Onuche Iboyi ${ }^{*}{ }^{1}$ Ogala Harrison ${ }^{1}$ and Jummai Suleiman ${ }^{2}$
}

${ }^{1}$ Department of Chemistry, Faculty of Sciences, Admiralty University of Nigeria, Ibusa,

${ }^{2}$ Department of Science Laboratory Technology, Faculty of Sciences, Kebbi State Polytechnic, Dankingari, Kebbi State.

\section{ABSTRACT}

Background: Fish is known to be one of the cheapest sources of animal protein and have essential nutrients needed in human diets. The present study investigated the proximate and nutrient composition of three species of fish, Champsocephalus gunnari, Oreochromis niloticus, and hybrid catfish (Clarias gariepinus).

Methods: The sample collection, proximate and mineral analysis were conducted using the standard protocols of sample collections and chemical analysis.

Results: The results revealed that Champsocephalus gunnari, Oreochromis niloticus, and Clarias gariepinus contain moisture $(66.00 \pm 0.50 \%, 52.00 \pm 1.00 \%$, and $70.00 \pm 0.20 \%)$, crude protein $(9.20 \pm 0.1323 \%, 3.75 \pm 0.02 \%$ and $5.80 \pm 0.05 \%)$, crude lipid $(10.16 \pm 0.91 \%, 2.37 \pm 0.01 \%$ and $12.00 \pm 0.30 \%)$, ash $(11.92 \pm 0.02 \%, 39.40 \pm 0.03 \%$ and $11.97 \pm 0.06 \%)$, and crude fiber $(2.03 \pm 0.01 \%, 2.36 \pm 0.02 \%$ and $0.19 \pm 0.01 \%)$ respectively. The mineral contents were: iron $(4.50 \pm 0.01 \mathrm{mg} / \mathrm{kg}, 3.70 \pm 0.01 \mathrm{mg} / \mathrm{kg}$ and $4.70 \pm 0.02 \mathrm{mg} / \mathrm{kg})$, Zinc $(2.35 \pm 0.01 \mathrm{mg} / \mathrm{kg}, 2.15 \pm 0.0100 \mathrm{mg} / \mathrm{kg}$ and $(1.89 \pm 0.01 \mathrm{mg} / \mathrm{kg})$ for Champsocephalus gunnari, Oreochromis niloticus, and Clarias gariepinus respectively, while copper was only detected in C. gunnari $(0.25 \pm 0.01 \mathrm{mg} / \mathrm{kg})$. The same amount of chromium $(0.01 \pm 0.00 \mathrm{mg} / \mathrm{kg})$ was detected in all the samples. Manganese was undetected in all the samples.

Conclusion: In conclusion, the present study demonstrated the nutritional value of Champsocephalus gunnari, Oreochromis niloticus and Clarias gariepinus. This information would help in choosing any of the fish bases on their nutritional values rather than taste and other physical features.

Keywords: Proximate; Minerals; Champsocephalus gunnari, Oreochromis niloticus and Clarias gariepinus

Citation: Iboyi, N.O., Harrison, O. and Suleiman, J (2021). Proximate and minerals compositions of three species of fish, Champsocephalus gunnari, Oreochromis niloticus and hybrid catfish sold in Birnin Kebbi, Kebbi State, Nigeria. AROC in Food and Nutrition, 01(01);08-14

\subsection{Introduction}

Fish is one of the most important animal protein and other vital nutrients sources that are widely consumed by all races and classes of people, proper knowledge on the biochemical composition of fish finds application in several areas. Today there is an ever-increasing awareness about healthy food and fish is finding more acceptance because of its special nutritional qualities. (Andrew, 2001; Abolude and Abdullahi, 2005). Fish is widely accepted because of its high palatability, low cholesterol, tender flesh, cheap. (Eyo, 2001).

Fish is known to be one of the cheapest sources of animal protein and have essential nutrients needed in human diets (Sadiku and Oladimeji (1991). The advantages of fish as food are its easy digestibility and high nutritional value. The high demand for fish is not only because of its taste but also largely due to its nutritional values which is a function of its proximate composition (Njinkoue et al., 2016).

Fish flesh generally contains about 15-20\% protein and less than 1\% carbohydrates. Fish flesh or muscle naturally contains only traces or low levels of carbohydrates, in the form of sugars, sugar phosphates, and glycogen. Some other tissues such as the liver contain a larger amount of glycogen, and most molluscan shellfish also contain a fair amount of glycogen. (Mclay et al, 1986). Lipids from fish are well known as a rich source of long-chain $n-3$ polyunsaturated fatty acids (LC n-3 PUFA) such as eicosapentaenoic acid (EPA) and docosahexaenoic acid (DHA) which cannot be synthesized by humans and commonly 
obtained from the diet (Alasalvar et al., 2002). Polyunsaturated fatty acids from fish have been reported to have preventive and/or curative effects for several diseases including arterial hypertension cancers and inflammatory diseases (Turkmen et al.,2005). It may also aid in lowering the risk of Dementia, Alzheimer's diseases and prevent cardiovascular diseases ((Turkmen et al., 2005).

Fish have been one of the main food for many countries. It is a vital source of food for people. It is man's most important source of high-quality protein consumed by the world's population, according to the food and agricultural organization (FAO) of the United Nations (1997). In Africa, as much as $5 \%$ of the population, some 35 million people demand wholly or partly on the fisheries sector for their livelihood (FAO, 1996). In Nigeria, fish is a major food item contributing a total of $40 \%$ dietary protein requirements and a readily available source of animal protein in the diet of man (Adebowale, et al, 2008). Fish is highly nutritious with balanced amino acids, minerals, and vitamins for healthy human growth. It is less tough and more digestible when compared with chicken, beef, and mutton (Fagbenro et al, (2005).

Fish also has substantial social and economic importance. The value of fish traded internationally is about fifty-one billion US dollars per anum. Over 36 million people are employed directly through fishing and aquaculture (FAO, 2000). It is estimated that by 2050 , when the world population is projected to be over 9 billion, Africa will have to increase food production by $300 \%$, Latin America by $80 \%$, and Asia by $70 \%$ to provide minimally adequate diets for the projected population of 2 billion, 810 million and 5.4 billion people in the respective region (Fawole and Olagunju, 2007). These data show that a consistent source of fish is essential for the nutritional and financial health of a large segment of the world's population.

However, fish of various species do not provide the same nutrient profile to their consumers (Soriguer et al., 1997; Fawole and Olagunju, 2007; Takama et al., 1999). These differences in the nutritional compositions of different species may be attributed to food composition, food and feeding habit, feeding rate, habitats, sex, age, size, genetic traits, and season/migration (Dawson and Griman, 1980; Abdullahi, 2001; Ajah, 2009). Besides being used as food, fish is also increasingly demanded use as feed. However, information concerning the chemical composition of freshwater fishes, in general, is valuable to nutritionists concerned with readily available sources of low-fat, high-protein foods such as most freshwater fishes (Sadiku and Oladimeji, 1991; Mozaffarian et al., 2003; Foran et al., 2005) and to the food scientist who is interested in developing them into high-protein foods, while ensuring the finest quality flavor, color, odor, texture, and safety obtainable with maximum nutritive value (Elagba et al.2010). The aim of this study is to compare the proximate values and minerals of three selected different fishes and to help consumers in choosing fish based on their nutrient values.

\section{Material and methods}

\subsection{Sampling and sample preparation}

The samples required for this research work were three different species of fishes in Birnin Kebbi. Two were gotten from the Birnin Kebbi main market (Sabuwar kasuwa), they are Local tilapia fish (Nile tilapia) (oreochromis niloticus) and mackerel icefish (Champsocephalus gunnari) the third sample was obtained from a fish farm (Halil poultry and fisheries Badariya Area Birnin Kebbi) i.e hybrid catfish (Clarias gariepinus). They were collected and transported to the laboratory in their fresh forms in separate containers. The sample was separately minced and pounded in mortar and mixed. After pounding them, they were transferred as quickly as possible to a dry and rigid plastic container and sealed to avoid moisture loss or gain. They were clearly labeled, and stored in a cool environment (Edeoga et al., 2005).

\subsection{Reagents and Chemicals}

All chemicals used were of analytical grade and were products of Sigma Chemical Co., USA.

\subsection{Proximate Composition Analysis}

The proximate analysis of the moisture, ash, crude fiber, crude protein, and nitrogen was done using the standard method of the Association of Official Analytical Chemists, AOAC (1990). The sample was prepared in triplicate and the nitrogen was determined by the micro Kjeldahl method described by Pearson (1976) and the nitrogen content was converted to protein by multiplying it by a factor of 6.25. Carbohydrate was determined by the difference.

$\%$ carbohydrate $=100-(\%$ moisture $+\%$ ash $+\%$ fat $+\%$ protein) 


\subsection{Preparation of sample for ash content}

About $6 \mathrm{~g}$ of each sample was weighed into an already weighed crucible then the weight is taken. Few drops of glycerol were added to the samples and mixed. The sample in the crucible was gently heated over a Bunsen burner until it became charred and smoking ceased. It was then transferred to a muffle furnace and heated for about $24-48$ hours at $550^{\circ} \mathrm{C}$ until black ash resulted. Few drops of water were added to the blackened ash to dissolve the salt in the complex. The ash was dried in an oven and the ashing process repeated until grey ash resulted. It was cooled in a desiccator and the weight of the ash was taken. The same process was carried out on all the samples.

\subsection{Digestion of sample from ash}

A $15 \mathrm{ml}$ of concentrated $\mathrm{HCl}$ and $15 \mathrm{ml}$ of nitric acid were added to the ash in a crucible and boiled on a hot plate for 40 minutes for the complete removal of organic matter remaining. This was done in a fume cupboard and the acid was added as necessary to maintain the volume during boiling. The digested sample was filtered and transferred to a beaker after the crucible had been washed with distilled water. The volume of the extract was transferred into a $100 \mathrm{~cm}^{3}$ volumetric flask and made up to the mark with distilled water. The solutions were transferred into containers, corked, and labeled for the determinations of individual minerals (Yeshajahu, 2005).

\subsection{Determination of mineral elements using atomic absorption spectrophotometer (AAS)}

Analysis of mineral elements was carried out using atomic absorption spectrophotometer (AAS) using the standard method of the Association of Official Analytical Chemists, AOAC (1990).

\subsection{Statistical analysis}

Data collected were subjected to statistical analysis using the statistical package for social science version 21.0 and express as mean \pm standard error of mean (SEM). Statistical significance of the results between groups was determined using One-way analysis of variance (ANOVA) followed by Duncans multiple range test (DMRT) Differences in mean were considered to be significant at $p<0.05$ (Adamu and Johnson, 1997

\subsection{RESULTS}

\subsection{Proximate Composition}

The results of the proximate values of the three species of fish selected for this study are presented in table 1 . The moisture contents values were $66.00 \pm 0.50$ in C. gunnari, $52.00 \pm 1.00$ in 0 . nicoticus while $70.00 \pm 0.200$ in Clarias gariepinus. The crude protein values were $9.20 \pm 0.13$ ( $C$. gunnari), $\quad 3.75 \pm 0.03(0 . \quad$ nicoticu $)$ and $5.80 \pm 0.0500$ (Clarias gariepinus). O. nicoticus has the least $(2.37 \pm 0.01)$ while Clarias gariepinus $(12.00 \pm 0.30)$ has the highest rude lipid contents Carbohydrates and Crude fiber ranges from $2.03 \pm 0.01,2.36 \pm 0.02$ and $0.19 \pm 0.01$.

Table 1: The proximate composition of the fish species sold and consumed in Birnin kebbi.

\begin{tabular}{|c|c|c|c|}
\hline Proximate & C. gunnari & O. nicoticus & Clarias gariepinus \\
\hline Moisture $(\mathrm{g} / \mathbf{1 0 0 g})$ & $66.00 \pm 0.50^{a}$ & $52.00 \pm 1.000^{\mathrm{b}}$ & $70.00 \pm 0.20^{c}$ \\
\hline $\begin{array}{l}\text { Crude Protein } \\
\quad(g / 100 g)\end{array}$ & $9.20 \pm 0.13^{a}$ & $3.75 \pm 0.03^{b}$ & $5.80 \pm 0.05^{c}$ \\
\hline Crude lipid (g/100g) & $10.16 \pm 0.91^{a}$ & $2.37 \pm 0.01^{b}$ & $12.00 \pm 0.30^{c}$ \\
\hline Ash (g/100g) & $11.92 \pm 0.03^{a}$ & $39.40 \pm 0.03^{b}$ & $11.97 \pm 0.06^{\mathrm{a}}$ \\
\hline $\begin{array}{c}\text { Carbohydrate \& fiber } \\
(\mathrm{g} / 100 \mathrm{~g})\end{array}$ & $2.03 \pm 0.01^{a}$ & $2.36 \pm 0.02^{\mathrm{a}}$ & $0.19 \pm 0.01^{b}$ \\
\hline
\end{tabular}

Data are presented in mean standard deviation and Columns followed by the same alphabet are significantly similar. While columns followed by different letters are significantly different at $5 \%$ level of significance $(p$ $>0.05$ ) 


\subsection{Mineral Composition}

The results of the mineral content of the three species of fish selected for this study are presented in table 2 . The result for the values of the different minerals shows that Iron, Chromium, and Zinc are detected. Iron has the highest concentration of $4.70 \pm 0.0200(\mathrm{ppm})$ in Clarias gariepinus followed by $C$. gunnari with $4.50 \pm 0.0100$. Chromium has no significant difference between $C$. gunnariand $O$. nicoticus with 0.01 concentration. Manganese was not detected in all three samples, while Copper was only detected in C. gunnari with $0.25 \pm 0.0057$ (PPM) concentration.

TABLE 2: The mineral contents of the fish species sold and consumed in Birnin Kebbi

\begin{tabular}{|l|l|l|l|}
\hline Minerals $(\mathrm{ppm})$ & C. gunnari & O. nicoticus & Clarias gariepinus \\
\hline Copper & $0.25 \pm 0.01$ & undetected & Undetected \\
\hline Zinc & $2.35 \pm 0.01^{\mathrm{a}}$ & $2.15 \pm 0.01^{\mathrm{a}}$ & $0.89 \pm 0.01^{\mathrm{b}}$ \\
\hline Chromium & $0.01 \pm 0.00^{\mathrm{a}}$ & $0.01 \pm 0.00^{\mathrm{a}}$ & $0.01 \pm 0.00^{\mathrm{a}}$ \\
\hline Manganese & Undetected & undetected & Undetected \\
\hline Iron & $4.50 \pm 0.01^{\mathrm{a}}$ & $3.70 \pm 0.01^{\mathrm{b}}$ & $4.70 \pm 0.02^{\mathrm{a}}$ \\
\hline
\end{tabular}

Data are presented in mean standard deviation and Columns followed by the same alphabet are significantly similar. While columns followed by different letters are significantly different $(p>0.05)$.

\subsection{Discussion}

Fish is primarily composed of water $(66-81 \%)$, protein $(16-21 \%)$, carbohydrates $(<0.5 \%)$, lipids $(0.2-25 \%)$ and ash (1.2-1.5\%) (FAO, 1999). The proximate composition of nutrients in all fish samples showed variation among the individual species. The moisture contents of two species of the fish, (C. gunnari and Hybrid catfish) were within the acceptable level (60-80\%), which could be due to the stable water levels in the location where the fish were collected (Adewumi et al., 2014). Yeannes and Almandos, opined that differences in the nutrient composition of the fishes could be due to accessibility of these components in water, and/or the ability of the fish to consume and convert these vital nutrients either from food or water.

The percentage of water is also a good indicator of its relative content of energy, protein and lipid (Olagunju et al. 2012). Furthermore, biological variations, seasonal changes and environmental conditions are factors that can influence the biochemical composition of fish El Shehawy, et al (2016). Similar findings were reported by Adewoye and Omotosho (1997), Prapasri et al (199). The observed differences in the proximate compositions in the four fish species were not significant.

The percentage range of the moisture contents of fish species as observed in this study was between 52.00 and $70.00 \%$. The result shows that moisture is the major constituent of edible fish part. Moisture content in all the species agreed with observation of Udo and Arazu (2012), Olagunju et al., (2012), and Mazumder et al., (2008) in several freshwater fish species. The high moisture content can cause the degradation of polyunsaturated fatty acids, increase the fishes' vulnerability to spoilage by microorganisms, and consequently reducing fish quality for longer periods of preservation. However, high moisture content could also play important roles in metabolic reactions and help to easily solubilize certain elements. High moisture was also reported by Ayanda et al.

Protein and fat are the most important nutrient present in fish and their composition help to describe the nutritional status of a particular organism (Aberoumad and Pourshafi 2010). There were variations in the protein content of the three species examined in this study of $C$. gunnari, $O$. nicoticus, Hybrid catfish which showed high crude protein contents of and 9.20, 3.75, 5.80 respectively. The result revealed that all the analyzed species of fish were high-quality sources of protein. The high protein content in the tissue of the fish species in this study may be due to similarity in diet of the fishes that are very rich in protein, (Osibona O. 2005.).

The ash content measures of the total mineral content in the tissue, (Nair and Mathew 2001). It is also helpful in the development of the body and growth. O. nicoticus had the highest ash content $(39.40 \pm 0.0320)$ while $C$. gunnari had the lowest 
ash content (11.92 \pm 0.0208$)$. The high value of ash in the fish species is an indication of its high mineral content like magnesium, calcium, potassium, and zinc, (Emmanuel et al., 2011).

The carbohydrates and crude fiber level in all the samples were low, though Clarias gariepinus has the lowest. According to Mclay, (1986) fish flesh or muscle naturally contains only traces or low levels of carbohydrates and this is evident especially in Clarias gariepinus (0.19) where there might not even be a trace.

In the mineral elements, the difference in the level of Iron is significant, Copper was undetected in $O$. niloticus and Clarias gariepinus but present in a very low level in C. gunnari. Zinc level in all the samples has very low level significance difference, while Chromium level is the same in all the samples, Manganese was undetected in all the samples.

$\mathrm{Zn}$ is an essential metal known to play important roles in human metabolic pathways and its shortage can cause appetite loss, retarded growth, skin changes and dysfunction of the immune system (Malakootian et al, 2011). Zn was detected in all the three samples of the fish with concentrations of $(2.35,2.15$ and 1.89 respectively). High concentration of $\mathrm{Zn}$ can lead to death, stunted growth, and reproductive injury (Sorensen 1991). Excess Manganese can induce oxidative stress and toxic effects in aquatic organisms (Edward et al., 2013) but it was undetected in this study.

\subsection{Conclusion}

This study is all about the importance and nutritional value of three species of fish, champsocephalus gunnari, oreochromis niloticus and Clarias gariepinus as a good source of protein and other minerals values. The information on the nutritional values can also help in choosing any of the fish bases on their nutritional values rather than taste and other physical features.

\section{Authors' contributions}

This work was carried out in collaboration between all authors. Author Nathaniel Onuche Iboyi designed the study and performed the statistical analysis. Authors Jummai Suleiman wrote the protocol. Authors Harrison Ogala help in carrying out the analysis and wrote some of the protocol. All authors managed the analyses of the study and managed the literature searches. All authors read and approved the final manuscript.

\section{Funding}

No source of funding has been provided

\section{Competing Interests}

Authors have declared that no competing interests exist.

\section{References}

Abdullahi, S.A., (2001). Investigation on nutritional status of Chrysicthys nigrodigitatus, Barus filamentous and Aucheoglanis occidentalis (Family: Bagridae). Journal of Arid Zone Fisheries, 1: $39-50$

Aberoumad A., Pourshafi K. (2010) Chemical and proximate composition properties of different fish species Sobtained from Iran. World J. Fish Mar. Sci. 2010;2:237-239.

Abolude, D S, \&Abdullahi, S. A. (2005). Proximate and mineral contents in component parts of Clarias gariepinus and Synodontisschall from Zaria, Nigeria. Nigerian Food Journal 23:1- 8.

Adewoye S. O, Omotosho J. S, (1997) Nutrient Composition of some freshwater fishes in Nigeria Biosci. Res. Commun., 11 (1997), pp. 333-336

Adewumi A., Adewole H.A., Olaleye V.F. Proximate and elemental composition of the fillets of some fish species in Osinmo Reservoir, Nigeria. Agric. Biol. J. N. Am. 2014;5:109-117.

Ajah, P.O., (2009). Fish breeding and hatchery management. Jerry commercial productions, Calabar, p: 183.

Alasalvar, C. Taylor, K.D., Zubcov, E., Shahidi, F.\& Alexis, M. (2002). Differentiation of cultured and wild sea bass (Dicentrarchuslabrax): total lipid content, fatty acid and trace mineral composition. Food Chemistry; 79:145 150.

Andrew, A.E (2001): Fish Processing Technology. University of Ilorin press, Nigeria, pp 7-8.

AOAC. 1990. In: Helrich, K (Ed.), Official Methods of Analysis of the Association of Official

Ayanda O.I., Dedeke G.A., Ekhator U.I., Etiebet M.K. Proximate composition and heavy metal analysis of three aquatic foods in makoko river, Lagos, Nigeria. J. Food Qual. 2018;2018:6. 
Bamidele O. O. (2007) Introduction to fish farming in Nigeria. Ibadan University Press. Pp. 2-47

Clariasgariepinusand Chrysichthysnigrodigitatusof the Cross River, Nigeria. Pakistan Journal of Nutrition 11 (10): 865-868

Edeoga, H.O., Okwu, D.E. and Mbaebie, B.O. (2005). Phytochemical Constituent of Some Nigerian Medicinal Plants. African Journal of Biotechnology, 4(7): 685-688.

Edward J.B., Idowu E.O., Oso J.A., Ibidapo O.R. Determination of heavy metal concentration in fish samples, sediment and water from Odo-Ayo River in AdoEkiti, Ekiti State, Nigeria. Int. J. Environ. Monit. Anal. 2013;1:27-33.

El Shehawy S.M., Gab-Alla A.A., Mutwally H.M.A, (2016) Proximate and elemental composition of important fish species in makkah central fish market, Saudi arabia Food Nutr. Sci., 7 (2016), pp. 429-439

Elagba, H. A. M., Rabie, A. and Mansour, H. M.(2010). Proximate composition, amino acid and mineral contents of five commercial Nile fishes in Sudan. African Journal of Food Science 4(10): 650-654

Emmanuel B.E., Oshionebo C., Aladetohun N.F. Comparative analysis of the proximate composition of Tarpon atlanticus and Clariasgariepinus from culture systems in South-Western Nigeria. Afr. J. Food Agric. Nutr. Devt. 2011;11:5344-5359.

Eyo AA (2001) Chemical composition and amino acid content of the commonly available feedstuff in Nigeria in fish nutrition and fish feed technology. Proceedings of first national symposium on fish nutrition and fish feed technology held at niomarlagos: 15-26.

Fagbenro OA, Akinbulumo MO, Adeparusi OE, Raji AA (2005) Flesh yield, proximate and mineral composition of four commercial West African freshwater food fishes. J Anim Vet Adv 4: 848-851.

FAO (1997) Review of the State of World Aquaculture. FAO Fisheries Circular no.886, Rev.i.Rome, Italy.
FAO (1999) The State of World Aquaculture. FAO Fisheries Circular no.886, Rev.i.Rome, Italy.

FAO (2000) The State of World Aquaculture. FAO Fisheries Circular no.886, Rev.i.Rome, Italy.

Fawole AC, Olagunju TE (2007). Proximate mineral composition in some selected freshwater fishes in Nigeria. J Food Saf 9: 52-54.

Food and Agricultural Organization (1996a) Food for all poor issued on the occasion of the World Food Summit in Rome. FAO Rome: 64.

Foran, J.A, Carpenter, D.O, Hamilton, M. C, Knuth, B. A, \&Schwager, S. J. (2005). Risk based consumption advice for farmed Atlantic and wild pacific salmon contaminated with dioxins and dioxin- like compounds. Environmental Health. Perspective., 33: 552-556.Journal 23:1- 8.

Mazumder, M. S. A., Rahman, M. M., Ahmed, A. T. A., Begum, M. \& Hossain, M. A. (2008). Proximate Composition of Some Small Indigenous Fish Species (SIS) in Bangladesh. International Journal of Sustainable Crop Production. 3(3):18-23

Mozaffarian, M.,D, Rozenn, N.L, Lewis, H. K, Gregory, L.B, Russell, P.T, \& Davis, S.S. (2003). Cardiac benefits of fish consumption may depend on type of fish meal consumed. Circulation. 107: 13721382.

Njinkoue J.M., Gouado I., Tchoumbougnang F., Yanga Ngueguim J.H., Ndinteh D.T., Fomogne-Fodjo C.Y., Schweigert F.J. Proximate composition, mineral content and fatty acid profile of two marine fishes from Cameroonian coast: Pseudotolithustypus (Bleeker, 1863) and Pseudotolithuselongatus (Bowdich, 1825) NFS J. 2016;4:27-31.

Osibona O. (2005). Comparative Study of Proximate Composition, Amino Acids, Fatty Acids and Aspects of the Biology of Some Economic Fish Species in Lagos State, Nigeria; p. 218. Ph.D Thesis. 
Pearson D (1991) The Chemical analysis of foods. London, longman group limited: 107-109.

Prapasri P., Kunchit J, Eakkarach K, Kriengkrai V, Yupaporn N, Lalita B, (1992) Proximate composition of raw and cooked Thai freshwater and marine fish J. Food Compos. Anal., 12 (1999), pp. 9-16

Sadiku SOE and Oladimeji AA (1991) Relationships of proximate composition of late niloticus (I) synodontisschall (broch and schnider) and sarotherodongaliaeus (trewavas) from Zaria dam, Nigeria. Bioscience Research Community 3: 2940.

Soriguer, F., Serna, S., Valverde, E. (1997). Lipid, protein, and calorie content of different Atlantic and Mediterranean fish, shellfish, and mollusks commonly eaten in the south of Spain. European Journal of Epidemiology, 13: 451-463.

Takama, K., Suzuki, T., Yoshida, K., Arai, H. \& Mitsui, T. (1999). Phosphatidylcholine levels and their fatty acid compositions in teleost tissues and squid muscle. Comparative Biochemistry and Physiology Part B, 124, 109-116.

Turkmen, N., Sari, F. and Velioglu, S. 2005. The effect of cooking methods on total phenolics and antioxidant activity of selected green vegetables. Food Chemistry 93: 713-718.

Udo, P. J. and Arazu (2012). Investigation of the Biochemical Composition of Heterobranchuslongifilis,

Yeshajahu P. and Meloan C. E. (2005) Theory and Practice of Food Analysis 